\title{
https://doi.org/10.48009/1_iis_2006_138-143 \\ USING SEVEN PRINCIPLES TO IMPROVE THE INTRODUCTION TO MIS COURSE
}

\author{
Queen E. Booker, Minnesota State University, Mankato, queen.booker@mnsu.edu \\ Carl M. Rebman, Jr. The University of San Diego, carlr@sandiego.edu \\ Fred L. Kitchens, Ball State University, fkitchens@bsu.edu
}

\begin{abstract}
Most university business programs require an entry level general information systems course. Although students usually have some computer knowledge, they tend to lack the skills to adequately use business related software for analytical purposes. This paper shows the improvement in an introduction to MIS course over different semesters by utilizing Chickering and Gamson's seven principles for good practice in undergraduate education. The study compares student perceptions of course value at the end of the semester after completing the introductory course. The results suggest that the use of Internetbased technologies and incorporation of exercises related to upper division course provided better motivation for students to learn material than courses that were text-book only based courses.
\end{abstract}

Keywords: Information Systems (IS), Active Learning, IS Education, Online Education

\section{INTRODUCTION}

In March 1987 the American Association of Higher Education (AAHE) Bulletin first published "Seven Principles for Good Practice in Undergraduate Education." The principles, created by Art Chickering and Zelda Gamson [6] with support from higher education colleagues, AAHE, the Education Commission of the States, and the Johnson Foundation, distilled findings from decades of research on the undergraduate experience. These findings are listed in Table 1. While other examples of good practice in undergraduate education may exist, Chickering and Gamson's is perhaps one of the best known. [14].

Table 1. Seven Good Practices/Principles in Undergraduate Education [6]

1. Encourage student-faculty contact

2. Encourage cooperation among students

3. Encourage active learning

4. Provide prompt feedback

5. Emphasizes time on task

6. Communicates high expectations

7. Respects diverse talent and ways of learning
These seven principles have also been applied to other subject matters. For example Ritter [14] applied these concepts to geology courses, Billings and Connor [2] adapted them to nursing courses, Chial [4] applied them to ethics courses, and several others have applied them to online courses in general $[9,1$, $8,13]$. However, to the authors' knowledge no studies related to the seven principles were found focusing on information systems courses.

Given the apparent lack of studies in the area of information system course delivery, the authors adopted the seven principles in developing course structure and material to support a technology based introductory course in an attempt to determine if these principles could be applied to improve student learning and student satisfaction. The Internet was chosen as a major vehicle for course delivery. Although the principles may be addressed without technology, the Internet offers rich and efficient scaffolding for educators to address them.

The rest of this paper is organized as follows: first there is a description of the introductory course and its logistical features. This is followed by a discussion of the research methodology and how the results of each specific principle were applied as well as comments purported by the students. The paper concludes with lessons learned and potential future research possibilities.

\section{DESCRIPTION OF MIS COURSE}

The authors teach two sections of introductory MIS per semester, a course that has two one and onequarter hour lectures per week. Each section consists of approximately forty students. The majority of the class is first- and second-year students who plan to major or minor in a business administration discipline. Over the past two years, the authors have used the web-based course management software Desire2Learn to support classroom activities.

The Introduction to MIS course was taught using a standard introductory MIS textbook. The course technology was used primarily to share PowerPoint lecture notes, submit assignments and to complete 
examinations. Students were required to attend class: attendance was taken, "pop" quizzes were given, and bonus exercises were only completed during the class period. Thus, if students missed a class, they might also miss a quiz or an exercise. None of the quizzes or exercises was offered online. The course was primarily a content course, focusing on MIS and business terms and concepts, with few hands-on exercises with team-building and data analysis with spreadsheets and databases.

\section{RESEARCH METHODOLOGY}

This study was designed to determine the impact of the application of the seven principles towards information systems education. To accomplish this, students from previous introductory MIS classes were asked to evaluate their experience which was then compared to current student perceptions of the redesigned class which adopted the seven principles. During the last week of class students in a junior level management course were asked to complete a Likert-scale evaluation of the Introduction to MIS course from the previous semester. In addition, students enrolled in a current Introduction to MIS course were asked to evaluate the course.

The students enrolled in the junior level management class typically were also enrolled in junior level Finance, Marketing, Management, Operations Management, and International Business courses. The students were asked to rate the Introduction to MIS course in relation to their preparation for their upper division courses using a scale of one to five, where one was Not Very Useful and five was Very Useful. The students were asked specifically about the usefulness in terms of business terminology, Excel skills, Access (database) skills, team building skills, collaborative technology skills (e.g., communicating via email and other online technologies), critical thinking skills, and information literacy skills. The results are shown in Table 2: Prior Student Perception of Introduction to MIS Course.

The results from the survey appear to indicate that the students didn't perceive the course as valuable or useful to them. While a more advanced study would review alumni impressions, the introductory course is too early in the academic career to have a direct measurable impact. Also, the students in the business program receive a second MIS course prior to graduation, making it virtually impossible to attribute any learning to the introductory course. Therefore, this study attempted to obtain the responses from previous students.
Table 2. Prior Student Perception of Introduction to MIS Course

\begin{tabular}{|l|c|c|}
\hline Question & Mean & SD \\
\hline $\begin{array}{l}\text { Usefulness of Business } \\
\text { terminology }\end{array}$ & 3.9 & .21 \\
\hline Usefulness of Excel skills & 2.5 & 1.18 \\
\hline Usefulness of Access skills & 1.9 & 1.21 \\
\hline Usefulness of Team building skills & 1.7 & 1.63 \\
\hline $\begin{array}{l}\text { Usefulness of Collaborative } \\
\text { technology skills }\end{array}$ & 2.3 & .47 \\
\hline $\begin{array}{l}\text { Usefulness of Critical thinking } \\
\text { skills }\end{array}$ & 3.1 & .49 \\
\hline $\begin{array}{l}\text { Usefulness of Information literacy } \\
\text { skills }\end{array}$ & 3.1 & 1.21 \\
\hline Usefulness of the book & 1.3 & .24 \\
\hline Usefulness of assignments & 2.7 & .68 \\
\hline Usefulness of online material & 2.3 & .36 \\
\hline Overall usefulness of course & 2.1 & 1.3 \\
\hline $\begin{array}{l}\text { Would you recommend the course } \\
\text { as useful? }\end{array}$ & 1.8 & 1.7 \\
\hline
\end{tabular}

The second part of the study requested the responses from current students utilizing some additional questions related to the seven principles. These results are listed in Table 3: Current Student Evaluation of Intro to MIS. This survey instrument was distributed to two sections with forty students each for a total of eighty students. Seventy-three completed the course evaluation. The evaluation was also on a Likert scale of $1-5$ with 5 being high and 1 being low. Their results were used as a baseline for determining if students perceive a shift in the course with the increased used of technology to support the course.

\section{RESULTS}

The following section reports the qualitative results obtained from the study from each of the seven principles/good practices as mentioned in table one.

\section{Encourages Student-Faculty Contact}

Chickering and Gamson view communication as a major contributor to success, particularly contact with the instructor. The small class size for this study allowed for sufficient individual attention to students in the classroom. However, the use of the course management system to the class seemingly encourages students to take advantage of the flexible learning environment by completing materials on their own at their own pace. As such, means to enhance student-faculty contact became more difficult as students chose not to attend class. Rather than penalize students for not coming to class, the 
students were encouraged to contact the instructor via email by placing the email address in the main page, on the syllabus, and at the introduction and closure of exercise instructions. The students were also encouraged to post general questions in the discussion forum.

Table 3. Current Student Evaluation of Intro to MIS

\begin{tabular}{|l|c|c|}
\hline Question & Mean & SD \\
\hline Course as a whole & 2.7 & .21 \\
\hline Instructor contribution & 4.5 & .73 \\
\hline Use of class time & 2.7 & .13 \\
\hline $\begin{array}{l}\text { Instructor's interest in whether } \\
\text { students learned }\end{array}$ & 4.3 & 1.2 \\
\hline $\begin{array}{l}\text { Amount you learned in the } \\
\text { course }\end{array}$ & 2.3 & .38 \\
\hline $\begin{array}{l}\text { Evaluative and grading } \\
\text { techniques }\end{array}$ & 3.2 & .67 \\
\hline Course organization & 3.5 & .98 \\
\hline $\begin{array}{l}\text { Sequential presentation of } \\
\text { concepts }\end{array}$ & 4.0 & .24 \\
\hline $\begin{array}{l}\text { Student confidence in } \\
\text { instructor's knowledge }\end{array}$ & 4.0 & .69 \\
\hline Instructor's enthusiasm & 4.9 & .21 \\
\hline Answers to student questions & 4.7 & .51 \\
\hline Contact with instructor & 5.0 & 0 \\
\hline $\begin{array}{l}\text { Instructor encouraged } \\
\text { cooperation among students }\end{array}$ & 1.5 & 1.9 \\
\hline $\begin{array}{l}\text { Instructor provided substantial } \\
\text { and diverse learning experiences }\end{array}$ & 1.3 & 1.78 \\
\hline Instructor gave prompt feedback & 2.7 & 1.74 \\
\hline $\begin{array}{l}\text { Instructor emphasized deadlines } \\
\text { on tasks }\end{array}$ & 3.7 & .73 \\
\hline $\begin{array}{l}\text { Instructor clearly communicated } \\
\text { expectations }\end{array}$ & 3.0 & 1.3 \\
\hline $\begin{array}{l}\text { Would you recommend the } \\
\text { course? }\end{array}$ & 1.3 & .79 \\
\hline
\end{tabular}

According to Chickering and Ehrmann [5] "electronic mail, computer conferencing, and the World Wide Web increase opportunities for students and faculty to converse and exchange work much more speedily than before, and more thoughtfully and "safely" than when confronting each other in a classroom or faculty office. Total communication increases and, for many students, the result seems more intimate, protected, and convenient than the more intimidating demands of face-to-face communication with faculty." $[5,15]$ Although most students are familiar with email, the students were still introduced to email and email protocol at the beginning of the semester, use email to make announcements, and at the beginning of each week, use email to list the material to be covered during the week, assignments that are due, and how much the assignments are worth towards the final grade. Students were encouraged to send questions or comments as they use the class materials or attempt to complete assignments. Traditional office hours were still maintained.

According to Ritter [14], the use of email to enhance student-faculty contact depends, in part, on the student's prior experience with email and willingness to use it. The analysis of emails sent by students per semester remained steady at an average of five emails per student. The average did not increase with the lifting of the restriction that students had to attend class. Face-to-face communications did not vary either. Students attending office hours averaged 2 per hour with and without the restriction of class attendance. Responses from the course evaluation (Table 3) show that students believe email is effective at facilitating student-faculty communication, although written comments from some students showed they felt it was not a viable replacement for face-to-face communication. These results were consistent with the previous studies.

\section{Develops Reciprocity and Cooperation Among Students}

Chickering and Gamson [6] believe that learning is enhanced when it is more like a team effort than a solo race. Good learning, like good work, is collaborative and social, not competitive and isolated. Working with others often increases involvement in learning. Sharing one's ideas and responding to others' improves thinking and deepens understanding.

Study groups, collaborative learning, group problem solving, and discussion of assignments can all be dramatically strengthened through communication tools that facilitate such activity. To implement this principle, new types of assignments were created that taught basic MIS concepts such as enterprise-wide technologies, collaboration tools, networks, and database principles where students depended on one another but still had individual responsibilities. For example, in the second iteration of the course, the database development project changed from a standard transaction processing system with querying to a simple supply chain system where students were grouped into teams of four, with each having a different part of the supply chain. Discussion forums were established in Desire2Learn for asynchronous discussions while chatrooms were established for 
synchronous discussion and students were also encouraged to use email to communicate with each other about the assignments. The comparison of faceto-face meetings between the two samples showed the current student group had fewer conflicts with classmates over missed meetings as opposed to the prior students In addition the current students from the Spring had a higher satisfaction with group work than the prior student group.

\section{Encourages Active Learning}

Given that the class was partially based on a lecture format, much of the Internet materials that were developed were considered 'lectureware' which is material used during a traditional lecture [3] as well as 'courseware' which is material used by students outside lectures. Krygier [10] found that students who felt overwhelmed by the course content believed that having access to materials outside of class helped them learn the material better. The ability to cover material at their own pace, to skip material they already know, or to explore topics they are interested in, are examples of active learning allowed by the Internet [3]. The material covered online included hands-on exercises to test knowledge of basic spreadsheet and database skills, similar to the types of questions found on the Microsoft Certification Exam, the creation of formula and queries, examples of various types of databases discussed in the lecture material but not actually designed as homework such as Customer Relationship Management systems and Enterprise Resource Planning systems. The analysis of student use of online lectureware and courseware indicated that students liked the online material. The prior student group accessed the online material an average of twenty-three times per student. This was considered interesting when compared to the current student group which accessed the material at an average of forty times per student (this is also the semester we lifted the attendance restriction).

But, as Moser and Hanson [11] mention, "students could do certain activities ad nauseam and not learn a thing." Given this, students were asked about preparation for particular courses that were considered to be created in active learning methodology, such as Finance problems, forecasting, statistical process control, and Internet research. The prior student group indicated they did not feel adequately prepared for their upper division courses based on what was required and instruction given by the teacher; whereas the students in the subsequent sections felt better prepared as a result of the Introductory course.

\section{Gives Prompt Feedback}

Giving prompt feedback is essential for keeping students abreast of their progress. In many cases the standard time for feedback was one week duration. The feedback mechanism was then changed by creating a two part submission that also encouraged working with team members. Students were allowed to complete the quiz components as many times as possible to earn a perfect score. It was found that students felt this particular feature for the class was particularly helpful to indicate where they were going wrong and if needed, could email the instructor to help understand what they were doing wrong if they couldn't figure it out themselves.

In addition to the exercises, students were given immediate feedback on actual quizzes and exams as well as other types of exercises online. Online practice tests and review questions were provided in an attempt to provide students with prompt feedback regarding their understanding of course material. Students felt this enhanced their understanding of the material and provides them with an indication of when they need to go back and study certain topics more carefully.

\section{Emphasizes Time on Task}

The Internet allows our students and faculty to make effective use of time, both inside and outside the classroom. Effective use of time is particularly important for non-traditional students, who find it hard to balance school activities with job and family activities. Analysis of use and access of online material by student and by time showed students accessing the online material at various hours and days, with no pattern of preferred time or day.

A high percentage of students felt the Internet materials improved their lecture notes. Based on the assessment results, students who rely solely on the lectureware for the lecture material fared no worse than students who attended class face-to-face. This was determined by keeping attendance informing students that attendance did NOT affect their final grade. Students who attended face-to-face accessed the online material as often as their online counterparts. Students who attended face-to-face sessions had a GPA of 87.6 compared to online students whose had a GPA of 88.3. The mean difference was not significant. 


\section{Communicates High Expectations}

The expectations for the class is communicated on the first day, and repeated throughout the course. At the beginning of each online module as well as the email announcement expectations for a particular class was explicitly stated. Each quiz also restates the learning expectation and what the quiz or practice exam should demonstrate in terms of MIS concepts as well as skill building. By posting review questions and practice test questions on the Internet, this study attempted to reinforce what students to have learned in class, and thus the students have a good idea of what they are expected to know.

\section{Respects Diverse Talents and Ways of Learning}

As Ritter [14] states, "effective teaching recognizes and addresses differences in the abilities and learning styles of students." Using the course management technology when properly used, supports different styles of learning. Visual learners prefer seeing what they learn. Pictures and images help them understand what they are learning. Students who learn best by hearing are considered auditory learners. Those who learn best by sensing movement and position are kinesthetic learners. Tactile learners learn best by touch and manipulation of objects [7].

Access to high-quality graphics and a structured course outline help visual learners. The online, selfpaced tutorial is an example of respecting diverse talents and ways of learning. The modules incorporate text, graphics, and sound recordings benefiting both auditory and visual learners. These modules also offer an alternative to traditional lecture and lab activities, and thus provide alternatives for students who do not fare well in a conventional classroom setting.

\section{LESSONS LEARNED}

Responses to the student evaluation show that students felt that using the Internet in the classroom was helpful. These responses correspond with previous studies which found that $93 \%$ of students enrolled in a course using lectureware for the entire semester supported the use of multimedia in the classroom, and some confirmed it was essential to their learning [10].

However, the t-tests on the means of the evaluations of students actually enrolled in the class showed no significant differences between the prior and current students, indicating that the students felt no loss of learning with the increased dependency on the online material or the switch in course emphasis from highly conceptual to more direct material for upper division courses.

\section{CONCLUSIONS AND FUTURE RESEARCH}

Applying Chickering and Gamson's seven principles can provide an excellent basis for constructing online course materials to support students in a skillbuilding environment. However, this study only covers two semesters worth of evaluations. It is necessary to obtain more evaluations and while some may suggest that teaching skills will always be perceived as a better course than concepts and theory, this study presents arguments that it is necessary for the student to have an adequate balance of both, which is why the ultimate course combines both with the skill-building intertwined with the theory and conceptual material.

Another potential limitation of this study could be a result of the small size of the class. However, in the future, the instructors will have one class of 250 rather than two sections of 40 to teach. The next versions of the course will enable this study to determine if the particular implementation is significant to larger classes or only to smaller ones. Further, to maintain a focus on skill building for upper division courses, it is necessary to collaboration with instructors in those courses to obtain feedback on what is new or needed at the junior level. It also might be of interest to investigate whether or not to allow students to access tutorial material after completing the class to see if students find on-going access improves their learning experiences in the upper division course. Lastly, the seven principles concept needs to be applied in more courses for a better determination of its potential.

\section{REFERENCES}

1. Anderson, T., \& Joerg, W. (1996). WWW to support classroom teaching. Canadian Journal of Education Communication, 25(1), 19-36.

2. Billings, D.M, \& Connors, H.R (2006) Best Practices for Online Learning (http://www.electronicvision.com/nln/chapter02/ index.htm ) accessed 12 June 2006.

3. Cates, W.M. (1992) Fifteen principles for designing more effective instructional hypermedia multimedia products, Educational Technology, December, 5-11.

4. Chial, M.R. (Oct. 1998). Ethics, Preferred Practices and the Professoriate, ASHA Issues in 
Higher Education Newsletter (Special Interest Division 10), 2(2), 3-7.

5. Chickering, A.W., \& Ehrmann, S. (1996). Implementing the seven principles: Technology as lever. AAHE Bulletin, October, 3-6. Retrieved June $\quad 12, \quad 2006 \quad$ from http://www.tltgroup.org/programs/seven.html

6. Chickering, A.W. \& Gamson, Z.F. (1991) Seven principles for good practice in undergraduate education,New Directions for Teaching and Learning No. 47 63-69 (San Francisco, JosseyBass).

7. Connor, M.L., Wright, E., De Vries, L., Curry, K., Zeider, C., Wilmsmeyer, D. \& Forman, D. (1996) Learning: the critical technology (St Louis, MO, Wave Technologies International), http://www.wavetech.com/whtpaper/abttmwp.ht ml accessed 6 October 1999.

8. Hara, N., \& Kling, R. (2000). Students' frustrations with a Web-based distance education course. First Monday, 4(12). Retrieved June 20, 2004, from http://firstmonday.org/issues/issue4_12/hara/inde x.html

9. Kidd, T. (Oct 2005). Key Aspects Affecting Students' Perceptions Regarding the Instructional Quality of Online and Web Based Courses, International Journal of Instructional
Technology and Distance Learning, 2(10), 5561.

10. Krygier, J.B., Reeves, C., Dibase, D. \& Cupp, J. (1997). Design, implementation and evaluation of multimedia resources for geography and earth science education, Journal of Geography in Higher Education, 21, 17-39.

11. Moser, S. \& Hanson, S. (1996). Notes on Active Pedagogy: A supplement to the active learning modules (Washington, D.C., Association of American Geographers).

12. Newham, R., Mather, A., Grattan, J., Holmes, A. \& Gardner, A. (1998). An evaluation of the use of Internet sources as a basis for geography coursework, Journal of Geography in Higher Education, 22, 19-34.

13. Polloff, R. M., \& Pratt, K. (2001). Lessons from the cyberspace classroom. San Francisco, CA: Jossey-Bass.

14. Ritter, M.E. (1997). Earth Online: an Internet guide for earth science (Belmont, $\mathrm{Ca}$, Wadsworth Publishing).

15. Redenstine, N.L. (Feb 1997). The Internet and education: A close fit. Chronicle of Higher Education, 21, A48. 